\title{
The phases of culture shock engaged by the main character Sashi as reflected in English Vinglish film
}

\author{
1Thalitha Natasya Fitri, 1Afina Murtiningrum* \\ ${ }^{1}$ English Literature, Universitas Islam Sultan Agung, Indonesia
}

\author{
*Corresponding Author \\ afina@unissula.ac.id
}

\begin{abstract}
This study explores the culture shock portrayed in Sashi's character of English Vinglish film by Gauri Shinde. The purpose of this study is to describe the kinds of phases of culture shock engaged by Sashi as the analyzed character. This study used descriptive qualitative method. The English Vinglish film by Gauri Shinde and the film script were the primary data of the study, whereas, the secondary data were taken from the books, journals, and articles that related to the research. The results of the study shows that Sashi as the main character in English Vinglish film encounters four phases of culture shock; they are honeymoon, crisis, recovery, and adjustment.
\end{abstract}

Keywords: culture shock; English Vinglish; Sashi; adjustment

Received:

31 May 2020
Revised:

18 July 2020
Accepted:

25 July 2020
Published:

31 August 2020

\section{INTRODUCTION}

Culture is arts, behaviour, values and attitudes which is unique and very interesting. Indeed, every country in the world has a different culture as a heritage from their ancestors that must be preserved from generation to generation. Culture in another word is the way of life and must be shared and followed by people in a society. There are a lot of cultural differences in this world, such as foods, custom, literature, art, and etc. According to Oatey (2008), culture is beliefs, policies and values which shared by a group of people and influence each member's behavior (p. 2). It can be said that culture is a result of the values which has gone through a long process of thinking and cannot be changed in a short time and as a combination of tradition, beliefs, behavior, habit, custom, and thought shared by people in society. Each culture has its own cultural uniqueness. "As people grow and live in cultural environment and they interact each other, culture will become their way of life, automatic and familiar" (Lopez, 2013, p.2). The results of cultural process itself are developed from generation to generation. It means that culture in a host country will be adopted by immigrants and this will form multicultural societies. 
Fitri, T.N., \& Murtiningrum, A. (2020). The phases of culture shock engaged by the main character Sashi as reflected in English Vinglish film. EduLite: Journal of English Education, Literature, and Culture, 5 (2), 334-344. DOI: http://dx.doi.org/10.30659/e.5.2. 334-344

Immigrants or sojourners are distinguished based on the duration of time someone lives in the host country. According to Ward, Bochner and Furnham (2005), sojourners are temporary residents who come to a new place or country for a certain period of time, whereas immigrants are people who relocate to a new country for long term resettlement. They usually will not return to their home country (p. 23). It means that sojourners do not live in a country for a long time. There is possibilities that they will return to their home country after accomplish their goals. The examples of sojourners categories are such as tourists, and overseas students. When immigrants and sojourners move to a new country, they will bring their own culture and also way of life. They need to learn and adopt the norms, customs and conditions of the new culture through socialization. "By bringing their own culture into another setting, they were faced different cultures. This condition will result culture clash which can affected into their personal and social level" (Lee and Kim 97).

In terms of culture shock, this theory was firstly introduced by Kalervo Oberg. He defined that "culture shock is embodied by the feeling of anxiety as a result from losing of someone's familiar social signs and symbols" (Yana, 2017 , p. 2). When people come to a new destination country, they have to deal with different culture. Therefore, they need to adapt with this new cultural environment in order to survive. A new research done by Ward (2005) believes that culture shock consists of four phases adaptation; that are honeymoon phase, crisis phase, recovery phase and the last is adjustment phase (81).

The culture shock phenomenon is portrayed in English Vinglish film by Gauri Shinde in 2012. The story of the film is full of conflicts, not only between Sashi as the main character and her family, but also Sashi and the society in the new country. Sashi is an Indian housewife and also a mother of two kids. She is described as a traditional Indian housewife who cannot speak English well. Sashi is often be the subject of mockery from her husband and children. She also finds it difficult to face the condition that forces her to speak English such as in school parents meeting. Sashi's daughter is more and more underestimate her and less respect of her because of her shortcomings.

The conflict continues to rise when she helps prepare the marriage of her niece in New York. She is scared of going to New York city alone for 5 weeks, meanwhile her husband and children come afterwards. After experiencing some accidents of culture shock and mostly because of her lack of English, she motivates to learn English by joining English class. Yet, the problem goes on. Culture shock problem still arises along with her learning English and her daily life in America, such as different attitude, food, the way people communicate each other, norms and etc. In the end of film, finally Sashi can adapt with the new culture because her ability to learn the new condition and accept the dissimilarities of those two cultures. Everyone experiences a time when he or she has to adapt to a new culture and he or she has to survive. In this film, the culture shock is experienced by Sashi because of facing American culture. The story clearly illustrates how Sashi as the main character experiences the phases of culture shock in America. 


\section{METHOD}

This study used descriptive qualitative research method. Which means that the process of gathering the data were done qualitatively and reported them descriptively. According to Ospina (2014), qualitative research is a systematic empirical inquiry into meaning of literary work (par. 2). It means that the researcher should have deep understanding toward the object of the study in order to get the data. Patton and Cochran (2002) also define that "qualitative research is characterized by its aims, which relate to understanding some aspect of social life, and its methods which (in general) generate words, rather than numbers, as data for analysis" (p. 1). So, qualitative data that has been obtained from observation are delivered in form of sentences descriptively. The purpose is to discover the answer of the problem formulation and to complete the analysis.

In organizing the data, this study used five steps, those are; 1) Watched the film, 2) Read the film script, 3) Identified the data, 4) Classified the data, 5) Reduced the data. The first basic of collecting data is watched the English Vinglish film. The aim of this step is to get the deep understanding toward the film. The researcher watched the film repeatedly to get the detail of the storyline. The second step is reading the film script after watching the English Vinglish film. The researcher read the film script for several times. The aimed for reading the film the script itself is to find the important points of storyline which going to be analyzed. After the film script was read closely, the third step is identified the data. It is done to find parts of the film that are going to be analyzed by highlighting and underlying the film script. The data were identified in form of monologues and dialogues of the characters. The next step is classified the data. It is required for making the analysis for answering problem formulation in chapter one. The data are gotten from the film script those are going to be written on a table called as appendices. The appendices consist of column of numbers, content of the film script, scene, type of analysis, references and comment. The detail of appendices is discussed in the analysis. The last step in the data collecting method was reduced the data. Reduced the data means a process of choosing the most important data from the film script which are going to be analyzed. Thus, the data is answer the problem formulation.

In this paper, the data were analyzed by using descriptive technique. The descriptive technique is stated by statement, description, and quotation. The reason choose the selected data because data supports the determination of problems. The results of the analysis was reported in finding and discussion. The supported data shown in the appendices. 
Fitri, T.N., \& Murtiningrum, A. (2020). The phases of culture shock engaged by the main character Sashi as reflected in English Vinglish film. EduLite: Journal of English Education, Literature, and Culture, 5 (2), 334-344. DOI: http://dx.doi.org/10.30659/e.5.2. 334-344

\section{FINDINGS AND DISCUSSION \\ Culture shock experienced by Sashi as the main character of English Vinglish film}

This study explores about culture shock experienced by Sashi in United States of America. She is shocked with the cultural differences between India and America, in terms of language spoken, foods, and the characteristics of people in host country.

\section{Language spoken}

There are a lot of cultural differences encountered by immigrants or sojourners in the host country. They will find habit, food, life style, and language spoken which different from their own. So does Sashi, as a sojourner, she engages culture shock experiences right after she arrived in American Airport. She is shock with the difference language spoken in America. It is aligned with Ricento's statement (2013) that "In the United States, many people feel to become an American one must speak English" (Par.6). Actually, English is not the official language of America. Its people come from various race and ethnic. They will speak in a lot of different language. Yet many people believe that they have to be able to speak English, because in schools teach English, people use English to communicate in its daily work, and everyone believes that English can help him to get a good job. This condition is different for India. Most of Indians are speak Hindi. It is in accordance with what Sourabh and Mansotra state that Hindi language is spoken by $30 \%$ of population of India, whereas 5\% of population uses English as their second language (30). The quotation is postulated in the film as follows:

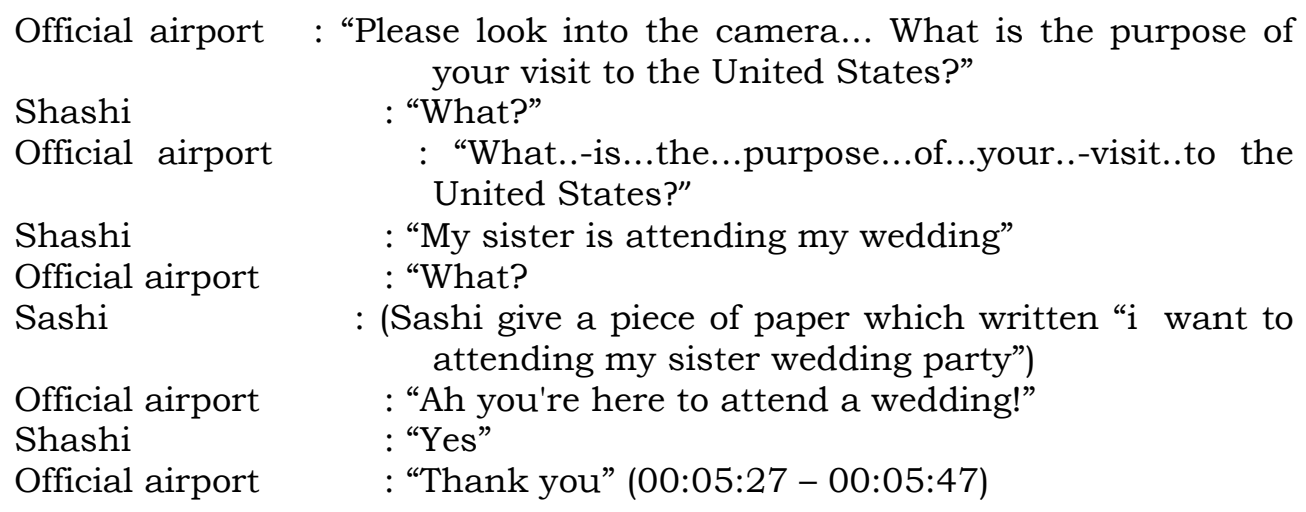

In the dialogue above, Sashi is shock with the difference language spoken in America. When the official airport asks Sashi about her purpose of visiting America, she does not understand, because she is only able to speak Hindi. So she is unable to communicate with the official airport. Finally, Sashi gives a piece of paper which written " $i$ want to attend my sister wedding party", and the official airport can understand.

\section{Food}

Language is not only as the problems of culture shock for Sashi but also food. She is shock with American food which different from her own. At night, 
Sashi, her sister, Radha, Meera and Meera's future husband are having dinner together. Sashi is confused with the strange food served to her. She just staring at the foods and she do not eat it. It is explained below:

Everyone is enjoying the food. They are seen so happy, except Sashi. She keeps holding the quesadilla and looks confused. She does not eat it.

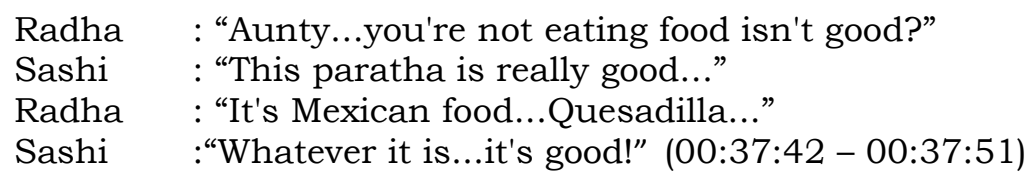

The dialogue above shows that Radha wonders why Sashi does not want to eat the foods while everyone is enjoying it. She is unfamiliar with the food served to her. Most of Indian is eating rice or special Indian food. Therefore, Sashi does not familiar with American food such as bread, cheese, and beef. It is aligned with what Lal (2019) states that, every region in India has its own food practices and etiquettes. Mostly, Indian people are eating rice, atta, paratha, vegetables, and salad (p. 12). Sashi is confused; she never tastes the quesadilla before. Quesadilla is made from corn tortilla and a pinch of cheese served with salsa and some guacamole on the side (Cullen, 2020, Par.1). The taste of quesadilla is different for Sashi, but she respects the culture by saying that the taste is good, she is affording to be polite.

\section{Characteristics of people in host country}

The different character between Indians and Americans is another problem of culture shock happen to Sashi. According to Linda A. Reed (1982), Americans are being "ruled by the clock". All things are well scheduled. Punctuality is important for them. People are expected to be on time for any occasion and events. Because of this condition, it cause Americans to be impatient and coarse when confront delay (p. 44). Americans are really appreciated and never waste time. People are seem in rush and they do everything deftly. This quotation denotes as follow:

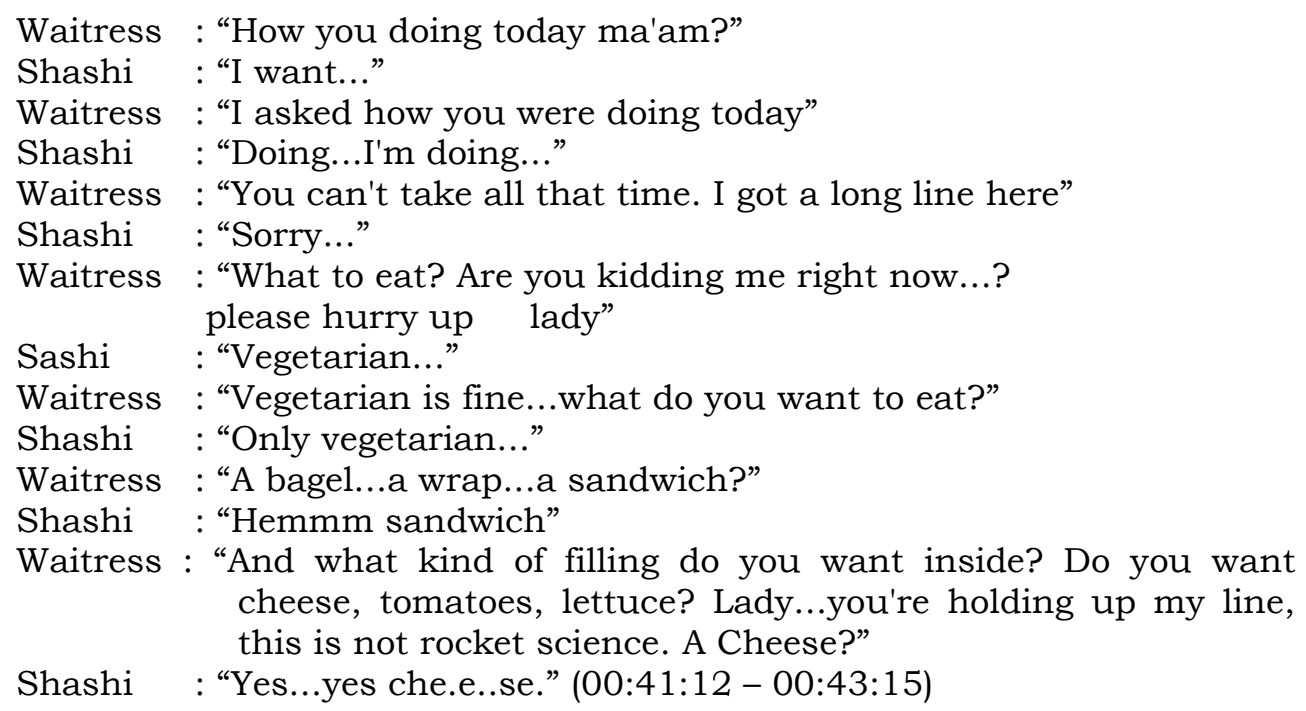


Fitri, T.N., \& Murtiningrum, A. (2020). The phases of culture shock engaged by the main character Sashi as reflected in English Vinglish film. EduLite: Journal of English Education, Literature, and Culture, 5 (2), 334-344. DOI: http://dx.doi.org/10.30659/e.5.2. 334-344

The dialogue above shows that the waitress of $O$ Cafe is angry with Sashi. Sashi is confusing what to order. She shocks with the culture and character of Americans which different than her own. The waitress is not nice, she spoke harshly and unfriendly. She looks impatiently waiting for Sashi to order because she is holding up the line.

Another proof which shows the different characteristics between Indians and Americans is postulated in the film as follows:

\section{Shashi : "Hello Satish, how are the kids? Have they gone to school? Have they taken their lunch boxes? Please do try to get home early. I'm feeling a bit strange here..without all of you..." \\ Satish : "Shashi...just enjoy yourself, I'm getting into an elevator..will talk later" (00:38:25-00:38:50)}

The story in the film tells that family is very important for Sashi. She spends a lot of time and energy with her mother, husband, and children. They are interdependent with each other. It is normal for Indians if family takes an important role in individual's life. This aligns with Jeff Heys statement's that "the family is an important institution that plays a central role in the lives of most Indians. Indians, as a collectivistic society, are always asserting loyalty and interdependence" (Scroope, 2018, Par.1). The condition is different from America, in which its people are individualist, because they only think about themselves. They do not like to interfere with other people's business. They do everything with their own capability. In accordance to the definition from Murwantono (2010), "The characteristics of Americans are hopeful, innocent, individualistic, pragmatic, and idealistic" (p. 2). From Sashi and Satish's dialogue, it can be concluded that Sashi is uncomfortable because she is far from her family. She is not used to it without the presence of her family. She has to manage everything in America by herself. People around her do not seem to care. It is different in India, where she can confide with others at any time.

\section{The phases of culture shock engaged by Sashi reflected in English Vinglish film.}

Every culture has its own uniqueness including customs and behaviours which still preserved from generation to generation. Lopez (2013) argues that actually culture is not born in every individuals. They can only learn, understand and imitate it. As they grow up, culture will become their habit and way of life (p. 2). For example, culture is learned when someone lives and interacts with people from different cultures. He adapts with them and imitates its culture naturally as they live together in society.

Therefore, culture become the way of life which gain through a long process. So it will difficult to change in a short time. This condition will result culture shock which can affected into individual personality. Culture shock was introduced by an anthropologist Kalervo Oberg. He believes that "culture shock is created by feeling of anxiety as a results from losing all someone's familiar social signs and symbols" (qtd. in Yana, 2017, p. 2). Someone need to adapt with situation of daily life such as how to communicate with other people, how to dress, how to give order to servants and etc. 
According to Oberg (1954), there are four phase of culture shock. This phase illustrated how a person adapt with new cultural environment. Another researcher also define this phase of culture shock but with different terminology as following: (1) Honeymoon phase, (2) Crisis phase, (3) Adjustment phase, and (4) Adaptation phase (Ward, et al, 2005, p. 81). As the main character, Sashi engages culture shock experiences during in America. She faced the new cultural environment in host country which different with her own. For example; the different language spoken, foods, characteristic of people, etc. Sashi undergoes the four phases of culture shock which finally makes her able to accept the differences between two countries. Here are the four phases of culture shock that experienced by Sashi.

\section{Honeymoon phase}

Ward, Bochner, and Furnham demonstrate there are four phase of culture shock. This phase illustrated how a person adapt with new cultural environment. The first stage of culture shock experienced by Sashi is Honeymoon phase. According to Ward, Bochner, and Furnham (2005), "honeymoon emphasis on the initial reactions of euphoria, enchantment, fascination, and enthusiasm" (p. 81). In this phase, mmigrants or sojourners are very enthusiastic to explore everything about a new country. This film tells that Sashi imagines various worry about goes to foreign country. In America, she encounters culture shock right after she arrived in American airport. The quotation of the film below portrays the Honeymoon phase experiences by Sashi:

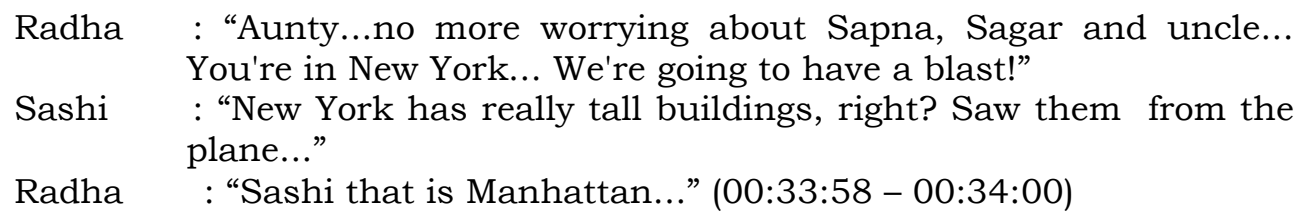

The quotation above shows the Sashi's feeling of enthusiasm and excitement. She is excited to explore and has high positive expectation about the new country. During the first few weeks, immigrants or sojourners will interest with the host country. They are interested to explore every part of the host country. Everything seems new, such as its custom, habit, traffic, and food that different than their own.

When Sashi arrived in America, she looks excited because it is her first time. She is picked up by her sister and niece in the Airport. She tells them that along the way she is amazed by the beauty of America. She sees so many tall buildings and beautiful surrounding of American country. Sashi has a positive expectations about living in New York. She calls her family in India, and she tells that she will enjoy to lives there and believes that everythings will be alright.

\section{Crisis phase}

Crisis phase is characterized by the feelings of anxiety and anger with cultural differences in a new country (Ward, et al, 2005, p. 81). Usually people who come and stay in the new destination country as immigrants even sojourners, they will experience crisis phase after they experience honeymoon. They will face a different cultural environment and habit. They might be fear and 
Fitri, T.N., \& Murtiningrum, A. (2020). The phases of culture shock engaged by the main character Sashi as reflected in English Vinglish film. EduLite: Journal of English Education, Literature, and Culture, 5 (2), 334-344. DOI: http://dx.doi.org/10.30659/e.5.2. 334-344

discomfort with the unfamiliar condition in the new country. They also feel that everything is strange, the people is different, the food, language spoken and etc. It is portrayed through these quotations:

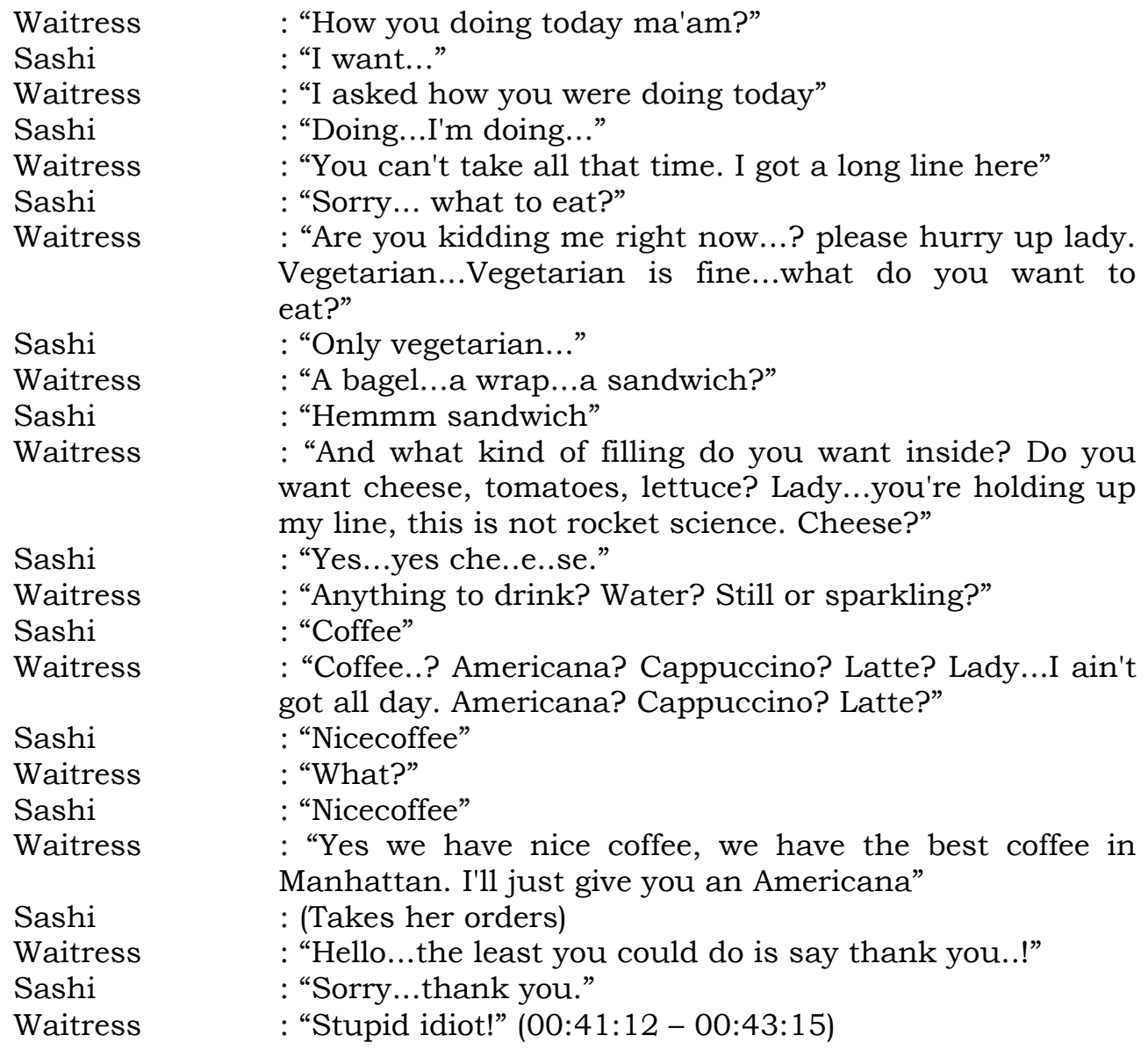

The dialogue above tells the moment Sashi accompanies her niece, Radha, to the campus. Sashi enjoys at Washington Square Park and waiting Radha to finish her class. All of sudden, she is hungry and she goes to a coffee shop. The crisis of cultural shock phase experienced by Sashi in America is in O Cafe. Sashi orders some food and beverages but the waitress is not nice. She is difficult to understand what the woman says because she speaks in English very fast. So it causes a small accident and then she leaves the cafe and forgets to take her order.

\section{Recovery phase}

The next phase of culture shock is recovery. When the immigrants or sojourners are trying to learn the language and begin to get around by theirselves, it means that they will to adapt with the new cultural environment (Oberg, 1954, p. 3). When Sashi experiences crisis phase and she can counter with those condition, it means she begins to let herself accepts in a positive attitude and tries to adapt with the new culture. The quotation which shows the adjustment phase experienced by Sashi is postulated in the film as follows: 


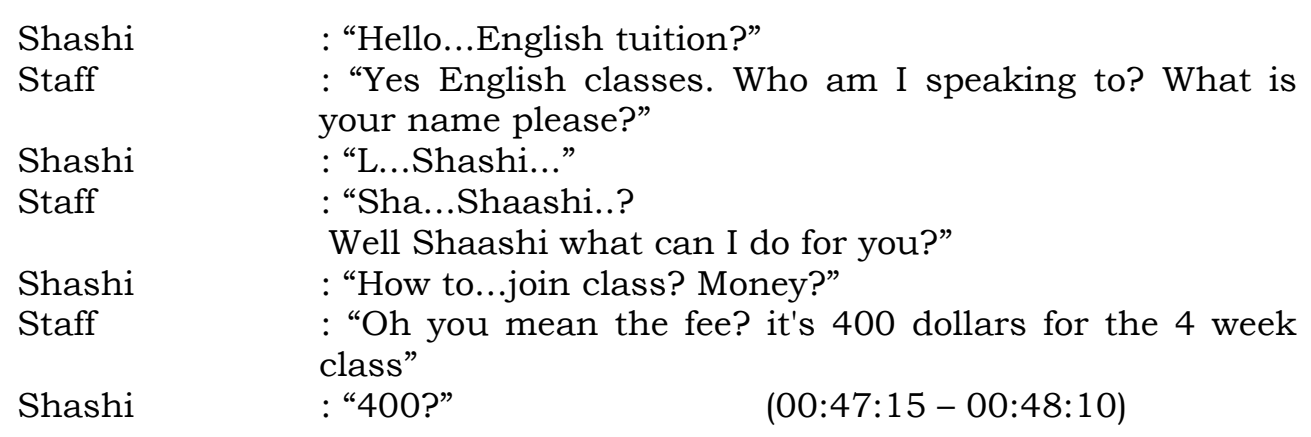

The dialogue above shows that Sashi is memorizing the phone number of New York Language Center which she sees in the body of bus and she calls them at home. She says that she wants to join the class and asks for the fee. This is in accordance with what Ward, Bochner, and Furnham (2005) state that "recovery phase is including crisis resolution and culture learning" (81). People who manage to deal with crisis phase of culture shock, they will experience adjustment phase. In this phase they begin to accept and learn the culture of the host country.

\section{Adjustment phase}

The last phase of culture shock experienced by Sashi is adjustment phase. In this phase, she begins to enjoy the culture and condition in the host country. She can overcome and adjust with the problem of culture shock. Like Ward, Bochner and Furnham (2005) stated that in this phase, individual is feeling comfortably and enjoy in the host country (p. 81). It is portrayed through these scene:

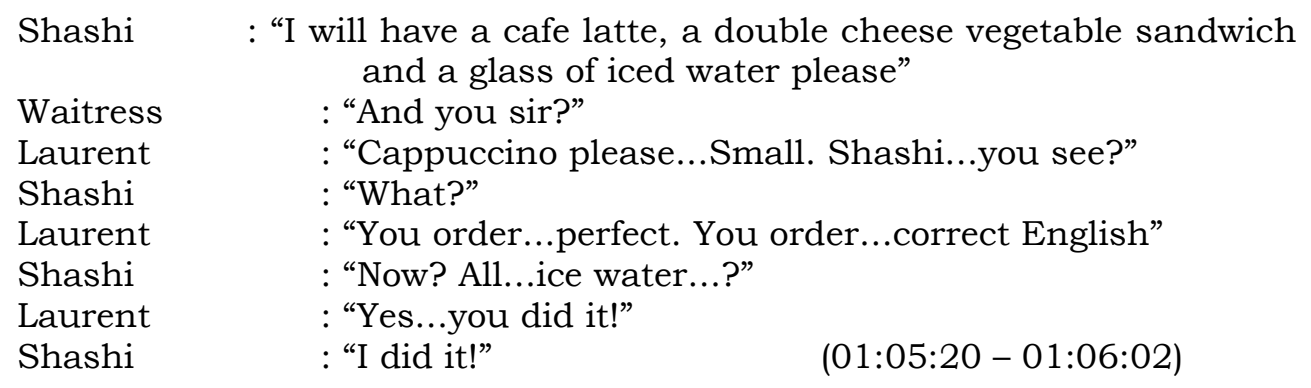

Sashi manages to adapt to the new cultural environment. It shows when Sashi and Laurent come to the same Cafe where she gets underestimate by the waitress before. It is because her inabilities of speak English. Now, Sashi is confident to order food using English fluently and does not afraid anymore. This situation is like what Winkelman (1994) states, "in this phase someone is successful at resolving problems and managing the new culture" (p. 122). After encounters the crisis and adjustment phase of culture shock, Sashi begins to enjoy with the cultural environment and adjust with the culture of the host country. Her confidence increases and she accepts the differences in America such as the foods, drinks, habits, customs, and lifestyles.

Sashi as the main character in the film is able to deal with all culture shock phase in America. As a sojourner, she can manage with crisis phase and adjust well with the new cultures, habits, customs and etc. One day, 
Fitri, T.N., \& Murtiningrum, A. (2020). The phases of culture shock engaged by the main character Sashi as reflected in English Vinglish film. EduLite: Journal of English Education, Literature, and Culture, 5 (2), 334-344. DOI: http://dx.doi.org/10.30659/e.5.2. 334-344

when she decides to visit or stay in America, she won't surprised with all the differences anymore.

\section{CONCLUSION}

Based on the analysis, it can be seen that this study has a conclusion that Sashi as the main character in English Vinglish film by Gauri Shinde has engages the culture shock experiences. Sashi encounters the four phases of culture shock during in America. Those are honeymoon, crisis, recovery, and adjustment.

When Sashi arrived in American airport, she has already in honeymoon phase. Sashi is excited to explore everything about American country. She has positive expectation and believe that she will be fine. Unfortunately, her excitement is only last a few days until she encounters culture shock for the first time. She is difficult to communicate with people. She is shock with the different culture, food, and habit which make her uncomfortable. Sashi then realizes that all of culture shock events that she experienced in America is because her inability in English. So she motivates to join English class. She begins to open herself with the society and learns culture from the host country. She is now in recovery phase. Sashi is able to manage the culture shock in America. Then, she experiences the last stage of culture shock that is adjustment. Now her confidence increases and she accepts the cultural differences in America. She has succeeded at resolving problems and managing the new culture.

Based on the conclusion above, this study derives several suggestions to the readers. It will be better if the next analysis does the further and specific research in order to find another aspect of English Vinglish film. Another researcher may analyze the film with another theory such as identity, anxiety, even psychoanalysis.

\section{ACKNOWLEDGEMENT}

Our deepest gratitude goes to the Dean of Language and Communication Science Faculty for supporting us to make this paper happen to publish.

\section{REFERENCES}

Cullen, D. (2020). Quesadillas and Sincronizades. Mexican Food Journal. 1.

Lal, R.M. (2019). An Overview of Indian Culture. Course BJMC 109. Retrived Jul, 20, 2019 from www.content.inflibnet.ac.id.

Lee, H-S. (2014). A qualitative study on the bicultural experience of secondgeneration Korean immigrants in germany. Pacific science review volume 16, issue 2, 97-109.

Linda, A. R. (1982). An Introduction to U.S. College and University Life. U.S.China Education Clearinghouse, 44. 
Lopez, A. (2013). Culture Shock Adaptation Strategies. Revista Nebrija de Linguistica Aplicada, 2.

Murwantono, D. (2010). Individualism of American Culture. Paper Material Teaching. Sultan Agung Islamic University, 3.

Oatey, S. (2008). Culturally Speaking. Culture, Communication And Politeness Theory, 4-15.

Oberg, K. (1954). Culture Shock. Presented To The Women's Club of Rio de Janeiro, 2-5.

Ospina, S. (2014). Qualitative Research. Encyplopedia of Leadership, 2.

Patton, M. Q., \& Cochran, M. (2002). A Guide to Using Qualitative Research Methodology. Medecins San Frontieres., 1-4.

Portillo, K. (2014). Culture Clash Vs Culture Shock. Mixed Nation, 3-5.

Ricento, T. (2013). Language Policy, Ideology, and attitudesin Englishdominant Countries. In Bayley, R., Cameron, R. \& Lucas, C. (Eds.), The Oxford Handbook of Sociolinguistics, Par. 6. Web. 23 Jan 2020

Scroope, C. (2018). Indian Culture. Cultural Atlas. Par. 1.

Ward, C., Furnham, A. \& Bochner, S. (2005). The Psychology of Culture Shock. Taylor \& Francis e-Librar, 5-81.

Winkelman, M.J. (1994). Cultural Shock and Adaptation. Journal of Counceling and Development, 122 .

Yana, Y. (2017). Adaptation Processes of Culture Shock In English Vinglish Movie As Understood By Students Of English Literature Departement. Adab And Humanity Faculty, 1-2. 